\title{
Air photo evidence of historical land cover change in the highlands: Wetlands and grasslands give way to crops and woodlots
}

\author{
Christian A. Kull
}

\author{
Monash University \\ Melbourne, Australia \\ E-mail: Christian.Kull@monash.edu
}

\begin{abstract}
Madagascar's high plateau - where people farm, graze cattle, and set periodic fire in a grass dominated landscape - receives disproportionately little conservation attention. An aerial photograph-based analysis of land-cover change in the latter half of the 20th century, based on a stratified random sample of twenty eight sites, reveals dramatic trends associated with an increasing human population that is building a cultural landscape of villages and agro-ecosystems to assure its livelihoods. On average across the sample sites, about $23 \%$ of grassland areas present in 1949-1950 were converted to crops fields, farm trees and built-up areas by the 1990s. Of all land-cover transitions, the most dramatic changes included the loss of approximately $60 \%$ of wetlands and $37 \%$ of riparian forests. These land covers, which are dispersed along the fine-grained dendritic stream network, are habitat for crayfish, frogs, and other fauna, yet are also prized locations in the rice-based Malagasy agricultural system. The results of this study suggest that attention be given to highland grassland, wetland and riparian forest ecosystem restoration and conservation; however, any on-the-ground initiatives should incorporate respect for local needs and allow sustainable use of these ecosystems, given their cultural and subsistence importance.
\end{abstract}

\section{RÉSUMÉ}

Les hautes terres malgaches, dominées par une végétation herbacée, sont des paysages fortement marqués par la gestion productive qu'y exerce l'Homme; qu'il s'agisse des pratiques culturales, de l'élevage ou de la manipulation des régimes du feu. Cette région ne reçoit généralement pas d'intérêt pour la conservation de la biodiversité. Cet article présente les résultats d'une étude régionale de changement d'occupation des sols et des dynamiques des formations végétales des hautes terres au cours de la deuxième moitié du XX ${ }^{e}$ siècle. L'étude est basée sur I'analyse de photographies aériennes prises entre 1949-1950 et 1990-1993 de 28 parcelles de 10 km² sélectionnées dans un échantillon aléatoire et spatialement stratifié. Les résultats confirment plusieurs tendances liées à l'implantation d'une population agricole croissante : 23 pourcent du terrain qui était couvert de formations graminéennes (herbeuses) en 1950 ont été remplacés par des champs pour l'agriculture, des plantations arborées et des zones résidentielles. Mais la catégorie de couverture végétale qui a été transformée le plus fortement est les zones humides (les marécages), dont la superficie a diminué de 60 pourcent. De plus, 37 pourcent de la superficie des forêts ripicoles ont disparu. Ces deux catégories de végétation humide, qui sont représentées par des parcelles de faible superficie distribuées le long du réseau hydrographique des hautes terres, sont des habitats importants pour les écrevisses, les amphibiens et d'autres éléments de la faune et de la flore. Ce résultat suggère que les efforts de conservation sur les hautes terres devraient se concentrer plus sur les zones ouvertes, les zones humides et les forêts ripicoles qui subsistent, au lieu de se concentrer sur les îlots de forêt sempervirente (qui, dans notre analyse, ont perdu 33 pourcent de leur superficie, mais qui sont bien représentés et protégés dans l'est du pays) ou de se focaliser sur les forêts sclérophylles (les bois de tapia, pour laquelle notre analyse confirme la stabilité). Étant donné I'importance culturelle et alimentaire des zones humides pour le système agricole (et surtout rizicole) des Malgaches, toute action de conservation doit d'abord chercher à respecter les besoins et les droits des habitants des zones rurales.

\section{INTRODUCTION}

Highland Madagascar - with its hilly grasslands, irrigated rice paddies, eucalyptus groves, and red adobe villages - gets relatively little conservation attention. For biodiversity enthusiasts, it is a landscape to be crossed en route from the capital city to the wet and dry forests skirting the east and west of the island, respectively. What research on biodiversity loss and conservation does exist in this region focuses either on peripheral montane closed canopy forests like Ambohitantely (Ratsirarson and Goodman 2000, Pareliussen et al. 2006), on large wetland areas in the mid-elevation Mangoro-Lake Alaotra basin (e.g., Rasoavarimanana 1997, Ralainasolo et al. 2006), or, after recent prioritization exercises (Kremen et al. 2008), on the highly-modified sclerophyllous tapia woodlands found on lee slopes (Kull 2003, Alvarado et al. 2010). The majority of the highlands landscape is thought to have been heavily modified through a long-term history of farming, domesticated grazing, and anthropogenic fire regimes, and constitutes a cultural landscape home to a significant part of Madagascar's population (Coulaud 1973), traditionally of lesser conservation interest (Raison 1984, Rakoto Ramiarantsoa 1995, Kull 2004, 2008).

This study aims to assess and quantify historic patterns of landscape change across the Malagasy highlands. In particular, 


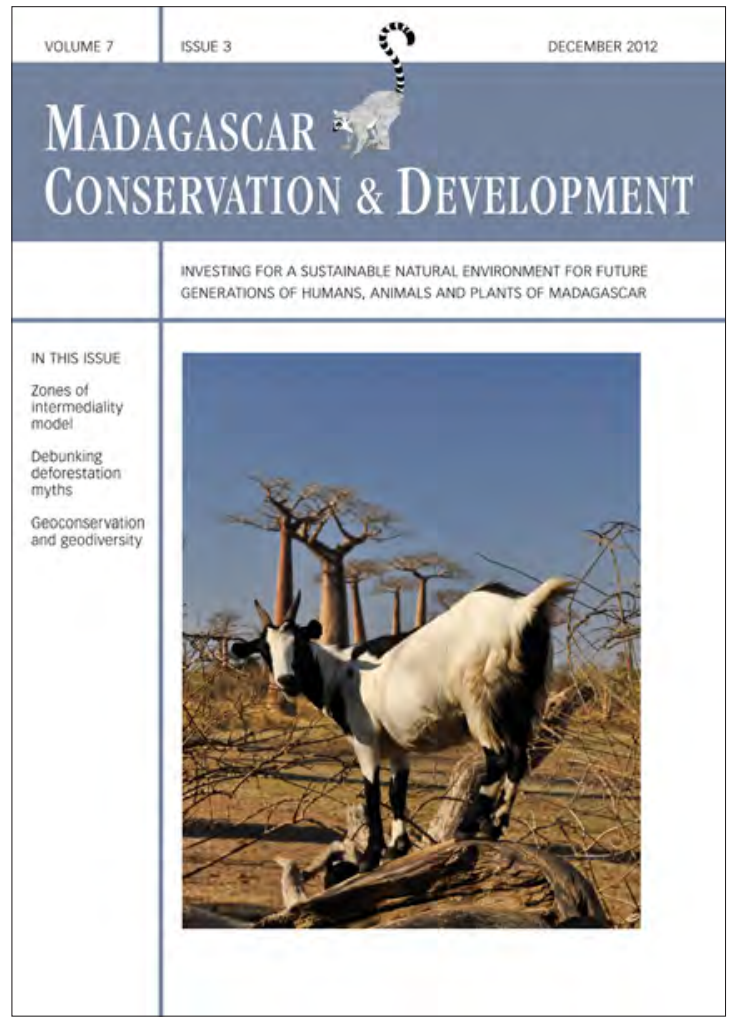

Madagascar Conservation \& Development is the journal of Indian Ocean e-Ink. It is produced under the responsibility of this institution. The views expressed in contributions to MCD are solely those of the authors and not those of the journal editors or the publisher.

All the Issues and articles are freely available at http://www.journalmcd.com

Contact Journal MCD

info@journalmcd.net for general inquiries regarding MCD funding@journalmcd.net to support the journal

Madagascar Conservation \& Development Institute and Museum of Anthropology University of Zurich

Winterthurerstrasse 190

$\mathrm{CH}-8057$ Zurich, Switzerland

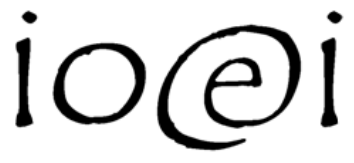

Indian Ocean e-Ink

Promoting African Publishing and Education www.ioeink.com

Missouri Botanical Garden (MBG)

Madagascar Research and Conservation Program BP 3391

Antananarivo, 101, Madagascar 
which types of vegetation cover - distinguished by physiognomy and by relative anthropogenic influence - are increasing, which are stable, and which are decreasing? From its findings, it then seeks to determine the implications for rural livelihoods and biodiversity.

Most land-cover change studies in Madagascar, which typically involve the analysis of remotely sensed data, have focused on biologically rich forest zones and forest margins, seeking to document large scale conversions between forest and non-forest categories (Green and Sussman 1990, McConnell 2002, Vågen 2006, Harper et al. 2007). Other studies have taken farmers or villages as their unit of analysis, describing land use changes in the context of rural demography, cultural land use, market stimuli, or institutional arrangements in particular highland case studies (Raison 1984, Rakoto Ramiarantsoa 1995, Kull 1998, Blanc-Pamard and Rakoto Ramiarantsoa 2000, McConnell and Sweeney 2005). In contrast, few studies using remotely sensed data to assess land-cover change have focussed on the regional vegetation cover dynamics outside major forested areas and at scales of investigation appropriate for studying rural land users and their livelihoods. This is in part the result of the reliance by remote sensing analysts on satellite-based data, which only became available in the 1970s (at relatively poor spatial resolution); it is also an outcome of the emphasis of the social science studies of land use dynamics or agrarian change on village case studies.

In order to analyze more detailed land use and vegetation categories, and to provide increased historical depth, this study employed manual interpretation of air photos. A trained aerial photograph interpreter can exploit the high spatial resolution and three-dimensional landscape representation offered by stereo pairs of photos in tandem with field experience to produce detailed and accurate maps of localized areas of interest, including minor patches of village trees, small wetlands in stream valleys, or fallow crop fields in grassland zones. It is sometimes even possible to distinguish between dominant species in forest and scrub patches. Historical aerial photograph archives exist for Madagascar as far back as 19491950, a half a century before satellite-based remote sensing provided similar levels of resolution. By comparing air photos from this period with the latest photos, from the 1990s, this study aimed to quantify land-cover trends across this highly modified landscape and consider the broader implications for both biodiversity and rural livelihoods.

\section{STUDY AREA}

The area of interest for this study is the central highlands of Madagascar, defined as the contiguous zone west of the rainforest escarpment within the former provinces of Fianarantsoa and Antananarivo, wherein valley bottoms exceed 800 meters in elevation (Figure 1). The reasons for this definition are as follows. First, the requirement for contiguity excludes outlying islands of higher elevation like Isalo or Bongolava that are arguably ecologically and culturally less similar. Second, the study area was bounded at the escarpment due to the much more humid climatic conditions east of the escarpment. Third, the $800 \mathrm{~m}$ contour has long been used as a biogeographic division (Humbert and Cours Darne 1965, Conservation International et al. 1995), though it is based more on a climatic than a fundamental phytogeographic split (Lowry et al. 1997). Finally, within

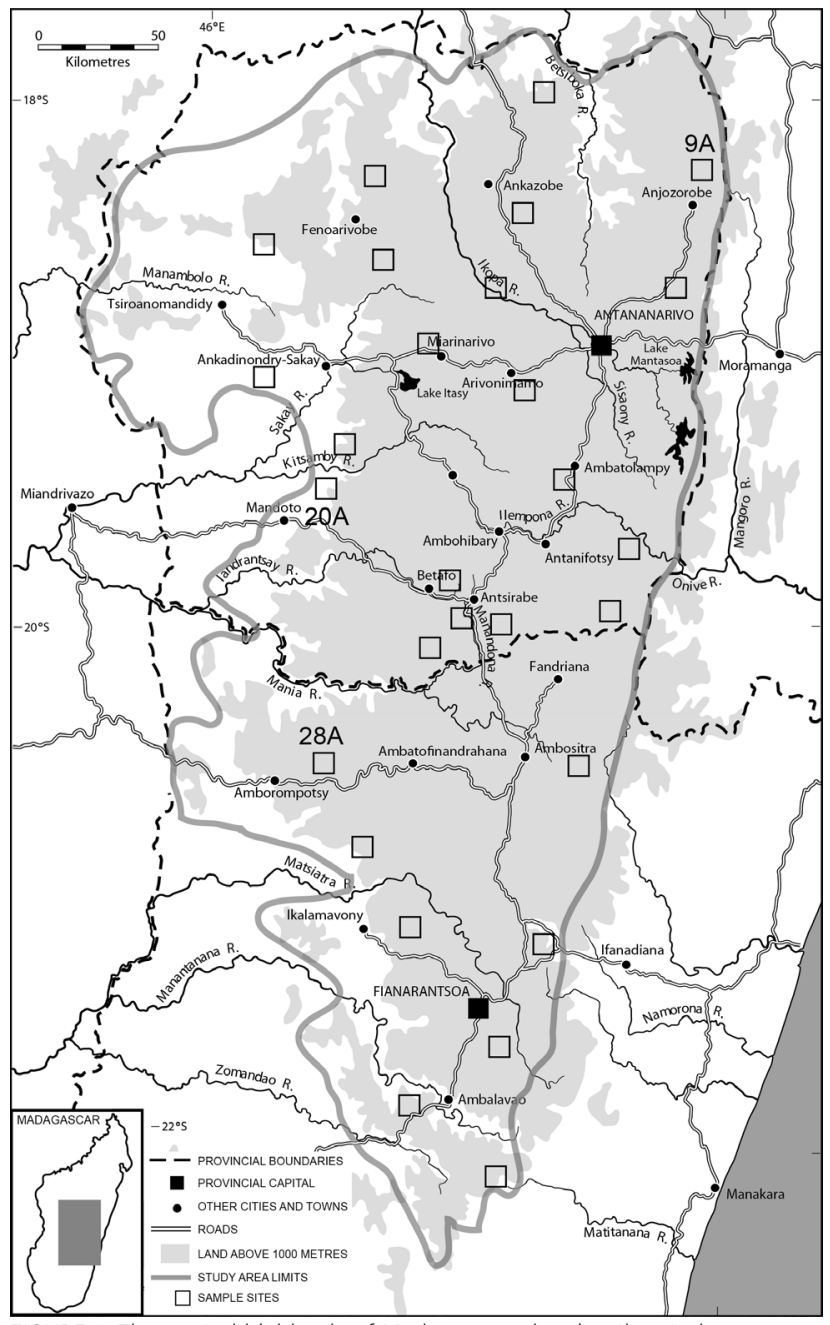

FIGURE 1. The central highlands of Madagascar, showing the study area limits (defined as the contiguous zone west of the rainforest escarpment, within Fianarantsoa and Antananarivo ex-provinces, wherein valley bottoms exceed $800 \mathrm{~m}$ ), and the locations of the stratified random sample sites.

this area, restriction to upland Fianarantsoa and Antananarivo ex-provinces maintains relative ethnic uniformity (the study area touches much of the current administrative regions of Analamanga, Bongolava, Itasy, Vakinankaratra, Amoron'i Mania, and Haute Matsiatra).

The resulting study area forms a rough triangle from Andringitra in the south, past Tsiroanomandidy towards the northwest, to the Anjafy plateau in the northeast. The region is dominated by herbaceous vegetation cover, with grasses like Heteropogon contortus, Aristida spp., Ctenium concinnum, and Loudetia simplex. The tropical highland climate varies from the warmer and drier mid-elevation west to the cool, wetter higher elevation east. The study area covers $80,000 \mathrm{~km}^{2}$, or $14 \%$ of the island.

\section{METHODS}

Aerial photographs were purchased from the national cartographic agency, Foiben-Taosarintanin'i Madagasikara (FTM), for the two temporal increments with full regional coverage: 1949-1950 (the oldest available) and 1991-1994 (the most recent available). The black and white photos measure roughly 20 by $20 \mathrm{~cm}$ (slightly smaller for the older series, slightly larger for the recent series), with a spatial scale of roughly 1:40,000. Camera focal lengths were obtained from FTM.

Owing to the high costs of time and labour associated with aerial photograph interpretation, stratified random sampling 
was employed to adequately represent variability within the area of interest. The study area was divided into a large grid based on half degrees of latitude and longitude. Each resulting grid square was then divided into $2^{\prime}$ by $2^{\prime}$ parcels $(n=225$ per grid square, $n=$ circa 4,050 for overall study area) and a parcel was chosen for each grid square using a random number generator. The choice of 2' by $2^{\prime}$ was based the correspondence of this dimension (approximately 3.2 by $3.8 \mathrm{~km}$ ) with the feasible area of air photo analysis from two or three overlapping air photos from two different overflights. If a sampled parcel was outside the area of interest, it was excluded from the sample and not replaced. The result was 28 sample sites.

For pragmatic purposes, some adjustments were made to the sample coordinates. First, for seven sample sites, the original parcel fell between two lines of air photos. These parcels were systematically displaced to the closest possible point (less than $1.5 \mathrm{~km}$ ) that provided photo coverage from a single line of photos. Second, key maps to the 1949-1950 air photo coverage affecting two sample sites were missing from FTM offices; in these cases an alternative sample site was created at the nearest point of air photo availability. Third, 1991-1994 air photo coverage is incomplete in northern and western Analamanga and Bongolava administrative regions; as a result, seven sites were moved to the nearest possible covered site. A final site had no nearby alternative, so oblique photographs were taken by handheld digital camera (3.2 megapixels) during a chartered overflight on 4 June 2003, making three passes at 2,400 m altitude and noting coordinates with a GPS (Garmin 12) (Warner et al. 1996).

Standard approaches to air photo analysis were followed (e.g., Vanacker et al. 2000), aware of many of the challenges that apply (e.g., McCusker and Weiner 2003). These include the fact that analyses based only on two time points can only surmise what happened in between, the fact that lumping together analyses from different years as a single time point may obscure short-term events, and awareness that seasonal and annual climate variability, time of day, and degradation of photo quality over time may affect the comparability of photos. Seasonality, in particular, is a factor not captured by the dry-season air photos, but which could be particularly relevant for wetland areas.

First, scanned air photos were orthorectified in ArcGIS using 1:100,000 topographic map sheets purchased from FTM, using numerous specific landscape features as tie points. Next, pairs of photos were analysed using a stereoscope, and land cover categories (Table 1, see also explanation below) manually mapped onto an A3 printout of an orthorectified air photo. All photos were analysed by the same observer (the author) to ensure consistent results. Finally, these classifications were digitized into ArcGIS, used to produce maps and areal coverage statistics for each class. Class conversion analysis based on pixel-to-pixel spatial registration was not undertaken, as the high topographic relief in the region causes geometric error making this unreliable (cf. McConnell 2002). The accuracy of the land cover statistics from this study is to within $0.01 \mathrm{~km}^{2}$ per $10 \mathrm{~km}^{2}$ sample site. This was assessed by spot check comparisons of the sums of the classification polygons between the 1949-1950 images and the 1990s images. This is at least an order of magnitude smaller than any changes in land cover found, lending confidence to the interpretation that these changes are not a result of operational error.
The land cover categories used (Table 1) warrant comment. The selection of categories is an artifact of what is visible and distinguishable on the photos, of traditions in remote sensing analyses, and of the interests of the researcher. The choice to separate or lump certain land cover types, the criteria by which they are distinguished, and the labels they are given can represent political agendas and have political implications (Robbins 2001, McCusker and Weiner 2003). In this study, the goal, as stated before, was to assess and quantify historic patterns of landscape change in the context of significant farmer-led land transformation and of interest in the potential impacts on native biodiversity. As a result, the categories seek to distinguish between, for example, natural and anthropogenic formations (recognizing the interpenetrated nature of these categories), and between specific physiognomic types of vegetation communities. The categories reflect to a large extent the opportunities and limits of the air photos and the conventions established in the science of aerial photography (Lillesand and Kiefer 1994) and in previous studies of Madagascar (Lowry et al. 1997). Yet they also in part reflect the distinctions made by farmers living in the landscape (like between categories C1 and C2, or tanimbary and tanety: Blanc-Pamard 1986, Kull 2008) as well as the author's research interests in fire (category BP: Kull 2004) and in the spread of Australian forestry species (category T9a: Kull et al. 2007). Except for the distinction of exotic and anthropogenic trees, the categories do not address floristic (or chorological) differences, like between different kinds of grassland vegetation communities, for this was not only beyond the scope of the

TABLE 1. Land cover classification categories used in the analysis.

\begin{tabular}{|c|c|c|}
\hline Code & Name & Notes \\
\hline$P$ & Pasture & $\begin{array}{l}\text { Grassland or pasture; may include isolated crop field } \\
\text { or tree }\end{array}$ \\
\hline $\mathrm{BP}$ & $\begin{array}{l}\text { Burned } \\
\text { pasture }\end{array}$ & $\begin{array}{l}\text { Recent fire scars in grassland; combined with P in } \\
\text { analysis }\end{array}$ \\
\hline $\mathrm{C} 1$ & $\begin{array}{l}\text { Irrigated } \\
\text { crops }\end{array}$ & $\begin{array}{l}\text { Irrigated fields (usually rice) on valley bottoms or } \\
\text { terraced slopes }\end{array}$ \\
\hline $\mathrm{C} 2$ & $\begin{array}{l}\text { Rainfed } \\
\text { crops }\end{array}$ & $\begin{array}{l}\text { Mostly continuous ( }>75 \% \text { ) cover of dryland rain-fed } \\
\text { crop fields (includes fallow) }\end{array}$ \\
\hline T1 & $\begin{array}{l}\text { Riparian } \\
\text { trees }\end{array}$ & $\begin{array}{l}\text { Trees/bushes along streams or in mountain side } \\
\text { hollows }\end{array}$ \\
\hline T2 & $\begin{array}{l}\text { Native } \\
\text { forest }\end{array}$ & $\begin{array}{l}\text { Continuous ( }>75 \% \text { canopy cover) non riparian native } \\
\text { forest }\end{array}$ \\
\hline T3 & $\begin{array}{l}\text { Native } \\
\text { woodland }\end{array}$ & $\begin{array}{l}\text { Discontinuous ( } 25 \%-75 \% \text { canopy cover) native } \\
\text { savanna or woodland, e.g. tapia forests }\end{array}$ \\
\hline T6 & $\begin{array}{l}\text { Farm } \\
\text { trees }\end{array}$ & $\begin{array}{l}\text { Anthropogenic trees including fruit } \\
\text { orchards, village trees, and especially pine } \\
\text { and eucalyptus woodlots }\end{array}$ \\
\hline T9n & $\begin{array}{l}\text { Natural } \\
\text { scrub }\end{array}$ & $\begin{array}{l}\text { Shrubby native vegetation, often heath or bracken } \\
\text { fern, usually on hilltops away from crops and habit- } \\
\text { ation }\end{array}$ \\
\hline T9a & $\begin{array}{l}\text { Anthrop } \\
\text { scrub }\end{array}$ & $\begin{array}{l}\text { Shrubby anthropogenic vegetation, often wattle or } \\
\text { coppiced eucalypts, usually near settlements }\end{array}$ \\
\hline B & Built-up & $\begin{array}{l}\text { Settled areas, including houses and bare ground; may } \\
\text { incorporate minor garden areas }\end{array}$ \\
\hline E & Erosion & Active bare soil erosion, especially lavaka gullies \\
\hline $\mathrm{L}$ & Lakes & Lakes, ponds \\
\hline W & Wetland & $\begin{array}{l}\text { Non-woody areas of visibly humid vegetation in topo- } \\
\text { graphic depressions }\end{array}$ \\
\hline $\mathrm{V}$ & Rivers & Large rivers \\
\hline R & Roads & Roads and tracks \\
\hline
\end{tabular}


study but also not possible without extensive fieldwork (Lowry et al. 2007). Identification of the different land cover types was based on analysis of textures and shades, 3-D topographic interpretation, and diverse clues in the landscape, relying on the author's familiarity with highland landscapes from previous fieldwork, and brief field visits to 12 of the sample sites.

The final step was the land cover change analysis, which involved comparing percentage cover of each land cover category in each sample site at the two time points. As the area of the sample sites varied slightly, changes in land cover across the collected sample sites were analysed using percentage change instead of actual areas, in effect normalizing the data. Average percentage changes, and their standard deviation, were calculated for each category across the 28 sample sites. A one-way analysis of variance test was used to test for statistical significance (Table 2).

\section{RESULTS}

The air photo analysis documents an expansion of anthropogenic land covers. This occurred largely at the expense of grassland, but proportionately wetland areas are the most affected (Table 2, Figure 2). While many sample sites display similar trends, there is considerable variability from site to site, reflecting accessibility, demography, state interventions, and biophysical context (three examples are illustrated in Figure 3). Below, the results are reviewed by category.

Grasslands [P and BP] dominate land cover in the highlands. Grassland area declined, on average, by $23 \%$ across the sample sites. The loss in grasslands areas is fully accounted for by a growth in crop field area, farm trees, and, to a lesser extent, built up village areas (houses, bare ground, and minor gardens). Irrigated rice fields [C1] and rain-fed crop fields [C2] occupied an eighth of all land in 1950, and had doubled to one quarter of land cover by the 1990s. Settlement areas of houses, bare ground, and minor gardens $[\mathrm{B}]$ and roads and tracks $[R]$ more than doubled. Farm tree coverage [T6, which incorporates

TABLE 2. Average percentage extent of land cover categories in 1949-1950 and 1991-1994, and gain or loss between these two temporal increments, across 28 randomly sampled sites in highland Madagascar. Standard deviation are in parenthesis; cf. Table 1 for description of land cover categories. *Gain or loss is statistically significant at $p<0.05$ based on one-way analysis of variance between 1950 and 1990s data for each category (from summary data, $\mathrm{n}=28$ ).

\begin{tabular}{|l|c|c|c|c|}
\hline $\begin{array}{l}\text { Land cover } \\
\text { category }\end{array}$ & $\begin{array}{c}\text { Average \% } \\
\text { cover } \\
\sim 1950\end{array}$ & $\begin{array}{c}\text { Average \% } \\
\text { cover } \\
1990 \text { s }\end{array}$ & $\begin{array}{c}\text { Average gain or } \\
\text { Ioss in \% cover, } \\
1950 \text { to 1990s }\end{array}$ & p-value* \\
\hline P + BP & $73.6(17.9)$ & $56.9(26.2)$ & $-16.7(15.6)$ & $0.007^{*}$ \\
\hline C1 & $5.8(6.4)$ & $9.7(7.6)$ & $+3.9(3.6)$ & $0.043^{*}$ \\
\hline C2 & $6.4(11.5)$ & $15.7(16.2)$ & $+9.3(10.0)$ & $0.016^{*}$ \\
\hline T1 & $1.9(3.3)$ & $1.2(2.3)$ & $-0.7(1.2)$ & 0.361 \\
\hline T2 & $0.2(0.6)$ & $0.2(1.0)$ & $0.0(0.4)$ & 0.855 \\
\hline T3 & $0.6(2.0)$ & $0.4(0.9)$ & $-0.2(1.2)$ & 0.631 \\
\hline T6 & $1.7(2.9)$ & $8.6(12.4)$ & $+6.9(11.6)$ & $0.006^{*}$ \\
\hline T9a & $0.5(1.8)$ & $0.7(2.3)$ & $+0.2(1.1)$ & 0.719 \\
\hline T9n & $1.9(3.4)$ & $1.6(2.6)$ & $-0.4(1.7)$ & 0.712 \\
\hline W & $5.1(4.8)$ & $2.0(2.0)$ & $-3.1(4.7)$ & $0.003^{*}$ \\
\hline B & $0.2(0.3)$ & $0.6(0.6)$ & $+0.3(0.4)$ & $0.003^{*}$ \\
\hline R & $0.3(0.5)$ & $0.6(0.8)$ & $+0.3(0.5)$ & 0.098 \\
\hline $\begin{array}{l}\text { other } \\
\text { L + V + E + } \\
\text { unclassified })\end{array}$ & $1.8(3.7)$ & $1.9(3.7)$ & $+0.2(0.6)$ & 0.92 \\
\hline
\end{tabular}

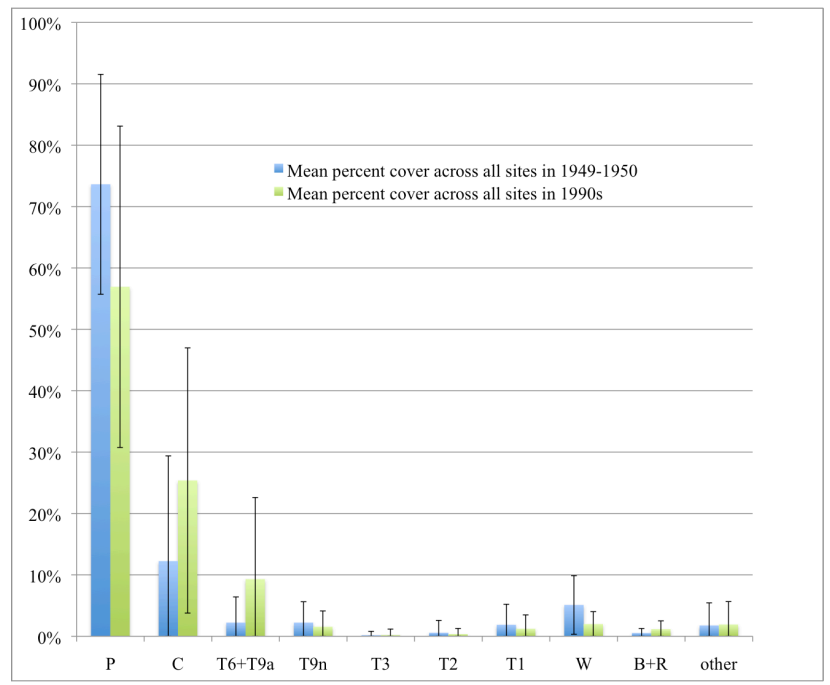

FIGURE 2. Gain, loss, or persistence of different land cover categories in highland Madagascar in the second half of the $20^{\text {th }}$ Century. Shows average percentage of each category (labels explained in Table 1) across the 28 sample sites. Error bars indicate standard deviations.

forestry plantations, private woodlots, fruit orchards, and village trees] quintupled, accompanied by a modest growth in anthropogenic 'scrub' [T9a, including harvested eucalyptus woodlots or spontaneous Acacia dealbata growth]. The vast majority of the area in these two categories is limited to a few species of eucalyptus, pine, and acacia (Rakoto Ramiarantsoa 1995, Carrière and Randriambanona 2007, Tassin et al. 2009a). These trends, except in the case of T9a, are all statistically significant (see Table 2).

The highland's small patches of natural forest [T2, closed canopy, non-riparian] declined by one third over the study period, whereas the tapia woodlands [T3], found in five sample sites, were stable. There was a slight loss in scrubland consisting of native ferns and heather [T9n]. None of the above trends are statistically significant. Proportionally, the most dramatic losses are of riparian forest (37\%) and wetlands $(60 \%)$; the latter is statistically significant. The former category [T1] includes vegetation ranging from gallery forests along streams to dense forest in mountainside hollows, and various intermediate categories, while the latter [W] includes non-woody vegetation areas in valley bottoms (seen in the air photos as visibly darker, thus moister, than surrounding grasslands).

\section{DISCUSSION}

The results largely correspond to what one would expect from a grassland region populated by a growing number of subsistence-oriented farmers: an expansion of anthropogenic land covers (Ellis and Ramankutty 2008), in particular crop fields, farm trees, and built up areas. The population of the island more than doubled during the study period, from 5.9 million in 1951 to 12.1 million in 1993 (SSG 1953, Repoblikan'i Madagasikara 1993), and the intensification of existing areas and conversion of new agricultural lands has been a primary occupation for much of the farming-based population (Raison 1984, Rakoto Ramiarantsoa 1995). The quintupling of farm trees that accompanied this activity reflects concerted efforts by farmers, government officials, and development agents to provide wood resources for fuel and construction, and to 'green' a perceived barren landscape (Carrière and Randriambanona 2007; Kull et al. 2007; Tassin et al. 2009b). 
A Site $9 \mathrm{~A}$
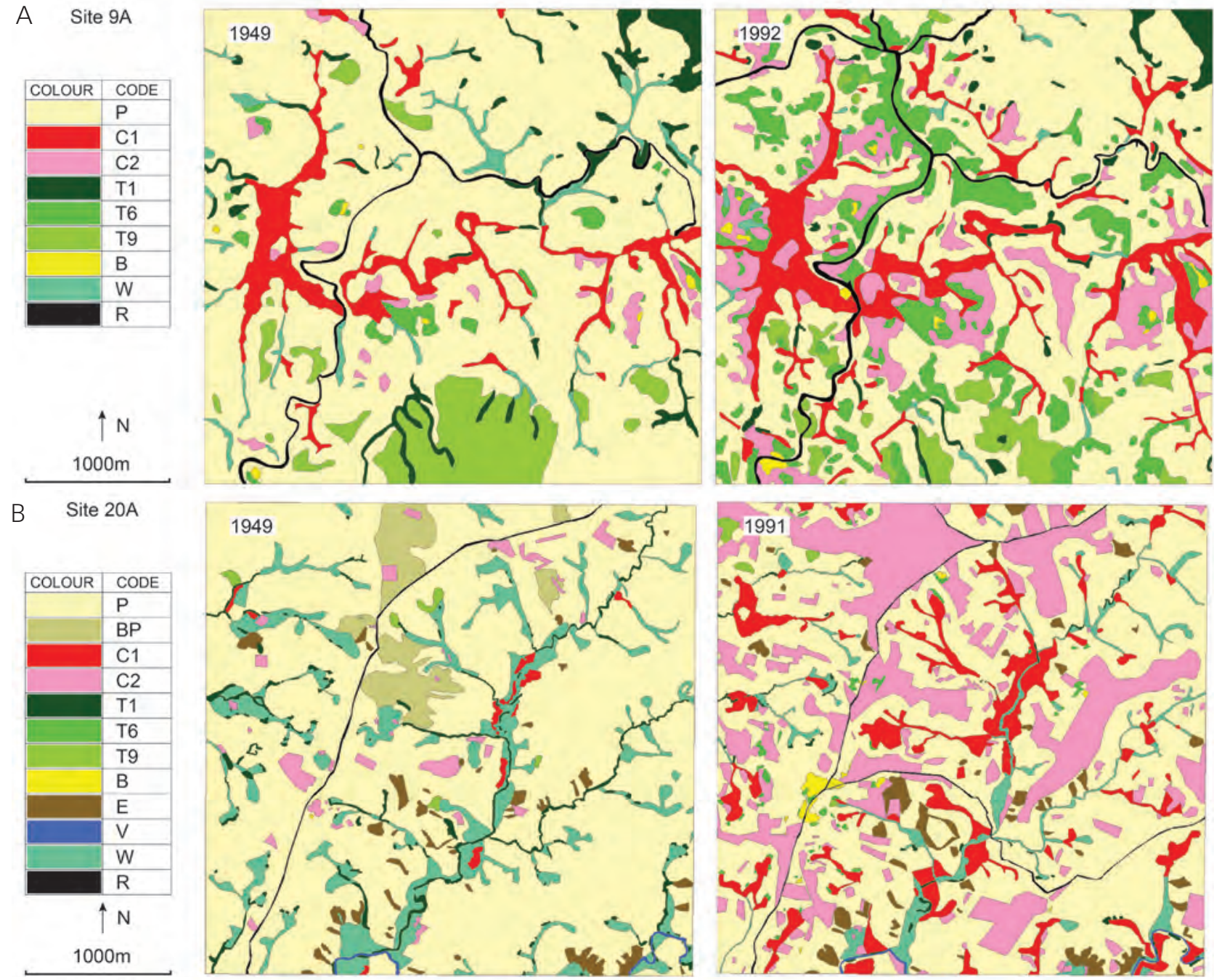

C Site 28A
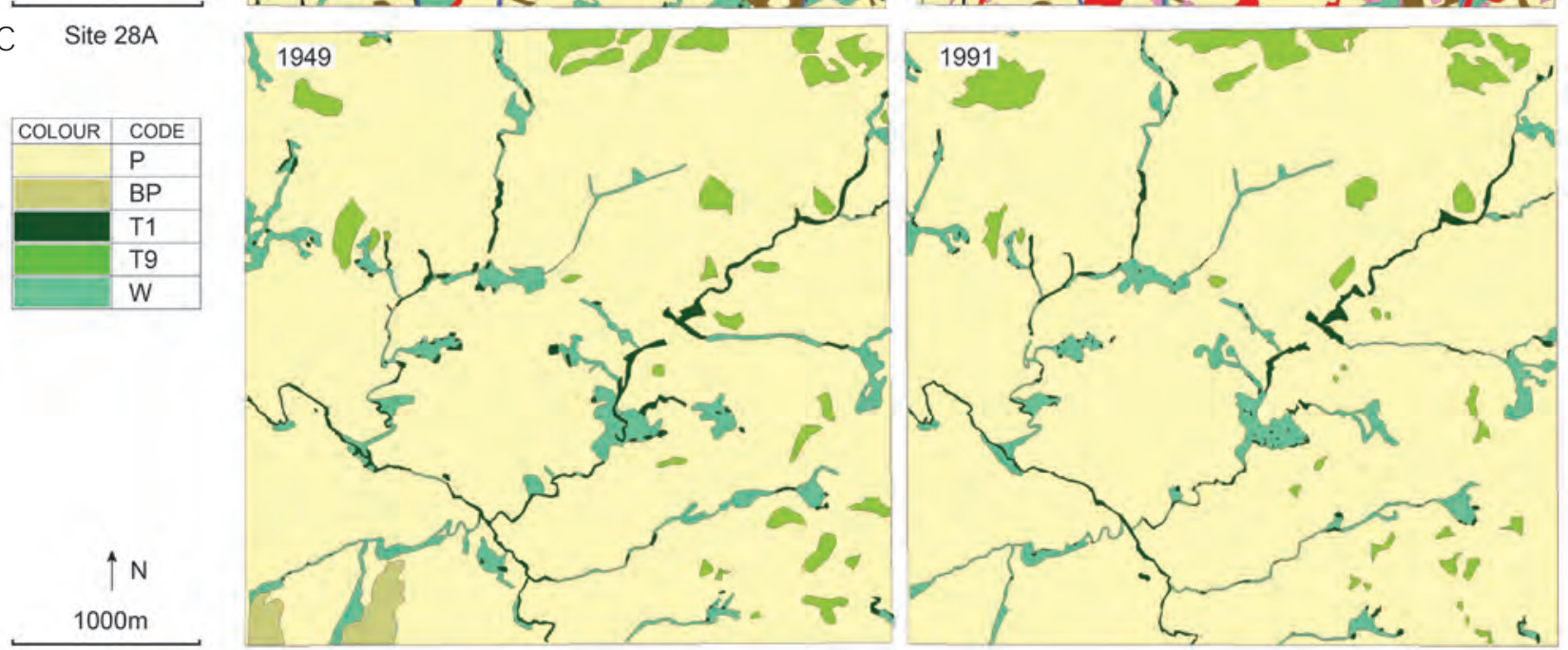

FIGURE 3. Land cover classification maps for three illustrative sample sites with different levels of human intervention (locations indicated in Figure 1; label codes explained in Table 1). (A) Site 9A, in the northeastern highlands, north of Anjozorobe, a zone of spontaneous agricultural and woodlot expansion; (B) Site 20A, in the western highlands near Mandoto, an area hosting several planned agricultural development projects; (C) Site 28A, an uninhabited area in the southwest of the highlands near the Col d'Itremo.

Malagasy farmers are creating cultural landscapes, using the constraints and opportunities of the landscapes, plants, technologies, and socio-economic relations they encounter (Kull 1998, Blanc-Pamard and Rakoto Ramiarantsoa 2000). These anthropogenic land covers incorporate many introduced plant species, some of which also blend into the spontaneous flora of grasslands and forests (Lowry et al. 1997, Kull et al. 2012).
The loss of natural closed canopy forest, though not statistically significant, corresponds with a trend broadly documented for Madagascar as a whole (Harper et al. 2007) as well as for the highlands at the edge of the forest escarpment near Ambositra (McConnell 2002, Vågen 2006) and at the outlying forest of Ambohitantely (Ratsirarson and Goodman 2000, Pareliussen et al. 2006). Forests likely succumbed to the combined pressures of 
tree cutting, crop field clearance, and fire. The relative stability, indeed slight increase though also statistically insignificant, of tapia woodlands corroborates findings reported in my previous studies of the woodlands south of Antsirabe (Kull 2003, 2004).

Grasslands, the dominant land cover, lost the most surface area during the 40-year study period: an estimated $13,000 \mathrm{~km}^{2}$ if one extrapolates from the sample sites. This broad land cover category includes a variety of herbaceous vegetation communities, in parts highly affected by human activities like grazing, fire and species introductions. The grasslands have long been described in many publications as a degraded, secondary formation characterized by a relatively small number of pan-tropical grasses and derived from woodier, richer pre-human land cover (Bosser 1969, Koechlin 1993, Gade 1996). However, recent research suggests that some Malagasy grasslands are of ancient origin and contain more diverse flora and fauna than previously recognized (Bond et al. 2008, Willis et al. 2008). Indeed, there is considerable debate over the origins of the grasslands, the nature of prehistoric highland vegetation, and the ways in which this history is framed (Lowry et al. 1997, Burney et al. 2004, Kull 2004, Gade 2008, Pollini 2010). This study reminds us that many grasslands are being transformed into other land covers in the creation of settled rural farming landscapes, and that much remains to be learned about their ecology and their historical dynamics in the face of climate swings, species arrivals, and human management. As Bond and Parr (2010) note, conservation attention to grasslands is long overdue.

The land cover categories that in percentage terms lost the most surface area during the latter half of the $20^{\text {th }}$ Century are the wetlands and riparian vegetation. These humid vegetation zones appear in the air photos as a dispersed, patchy, and veined network more or less following the dense, dendritic drainages of the highlands. They were part of the vegetation mosaic that at least partly characterized the pre-human Holocene period in the now grass-dominated highlands (Gasse and Van Campo 1998).

These humid vegetation zones are diverse in character. They include scattered patches of moist forest growing in the wet soil of mountain hollows and along first order streams where they are protected from free-ranging grassland fires (Figure 4A, B). Such forests are assumed to be floristically similar to the montane rainforests of the eastern escarpment, with genera Tambourissa and Weinmannia traditionally considered as indicative (DEF 1996). Downstream, thin gallery forests occasionally line riverbanks, including Mangifera indica, Ficus sp., and Breonadia salicina (Figure 4C). Finally, wherever the topography is flatter and impedes drainage, edaphic wetlands, marshes, and bogs have developed, featuring various native and introduced grasses, sedges, rushes, and herbs (Figure 4D).

These vegetation categories are frequently overlooked in mapping exercises, largely due to issues of scale. Their typically small size and thin shape is not conducive to satellite image-based remote sensing classifications (e.g., Conservation International et al. 1995, DEF 1996, Moat and Smith 2007). Some previous remote sensing-based studies of highland Madagascar land use do not even include wetlands as a land cover type (Razafindramanga Minoniaina 1994, Vågen 2006). The advantage of air photos lies in their higher level of detail and the potential for easy 3D viewing, which helps in identifying these vegetation types based not only on shade and texture, but also via topography.
Biologically speaking, several aspects of these dispersed, diverse humid vegetation types are poorly known, including their aquatic flora and the biology of freshwater invertebrates and fishes (Benstead et al. 2003). There are indications, however, that they are important. For instance, $30 \%$ of the vascular aquatic plants in Madagascar are found only in the island's Central phytogeographic domain (Andrianasetra Ranarijaona 2003), and all six species of freshwater crayfish (Astacoides) on Madagascar are found only above 800 m elevation in the eastern and central highlands (Jones et al. 2007). While the humid vegetation zones are widely altered by humans and the plants and animals we have introduced, they still serve important roles. For example, riparian forests can support the survival of some of the island's highly endemic montane frogs (Andreone et al. 2008, vences et al. 2009).

upland wetland conservation has not really found a place on the national conservation agenda outside of the long-standing efforts at Lake Alaotra - which is distinguished by the presence of a unique lemur population (Rasoavarimanana 1997, Ralainasolo et al. 2006, Copsey et al. 2009) and at Torotorofotsy marsh, which is a sizeable wetland site close to the popular Perinet/Andasibe protected areas complex (Rasoavarimanana 1997, Dolch et al. 2008). The lack of attention to other highland wetlands and riparian areas comes despite recognition in the literature that wetlands have been disproportionately fragmented, transformed, and modified by a long history of human land management (Durbin et al. 2003), with detrimental impacts on birds (Langrand and Wilmé 1993, Rabarisoa et al. 2003), aquatic flora (Andrianasetra Ranarijaona 2003), aquatic fauna (Elouard and Gibon 2001, Benstead et al. 2003), amphibians (Andreone et al. 2008), and freshwater fish (Benstead et al. 2003).

Several reasons might explain the lack of attention. Despite the fact that early colonial explorers noted the existence of the very localized, small, and dispersed network of humid vegetation in the otherwise grass-dominated highlands (e.g., de cointet 1897), they do not show up easily in today's remote sensing analyses. These zones understandably attract less interest than the larger, iconic, lemurhosting forests encircling the island. The tiny, dispersed patches would not fit easily into the dominant protected areas model for conservation.

Furthermore, wetland conversion is a culturally awkward topic, given the central role of irrigated rice farming to highland culture and food security. In all corners of the highlands, one of the first things that farmers do when settling new lands - which is an ongoing practice - is to establish rice fields in the most accessible marshes or floodplains (Delenne 1970, Rakoto Ramiarantsoa 1995, Kull 2008). In forest areas, conservationists (and colonial foresters before them) have long encouraged farmers to abandon slash-and-burn techniques in favor of more intensive, irrigated rice. So to discourage wetland conversion for conservation confronts the alimentary and cultural needs of a growing population and even the previous messages of government officials and conservationists. Fortunately, a fair number of first order catchments with humid vegetation remain in higher altitudes, in places far from roads, or in the lightly populated western highlands. Any conservation efforts in these areas would need to be based on further study in collaboration with local 

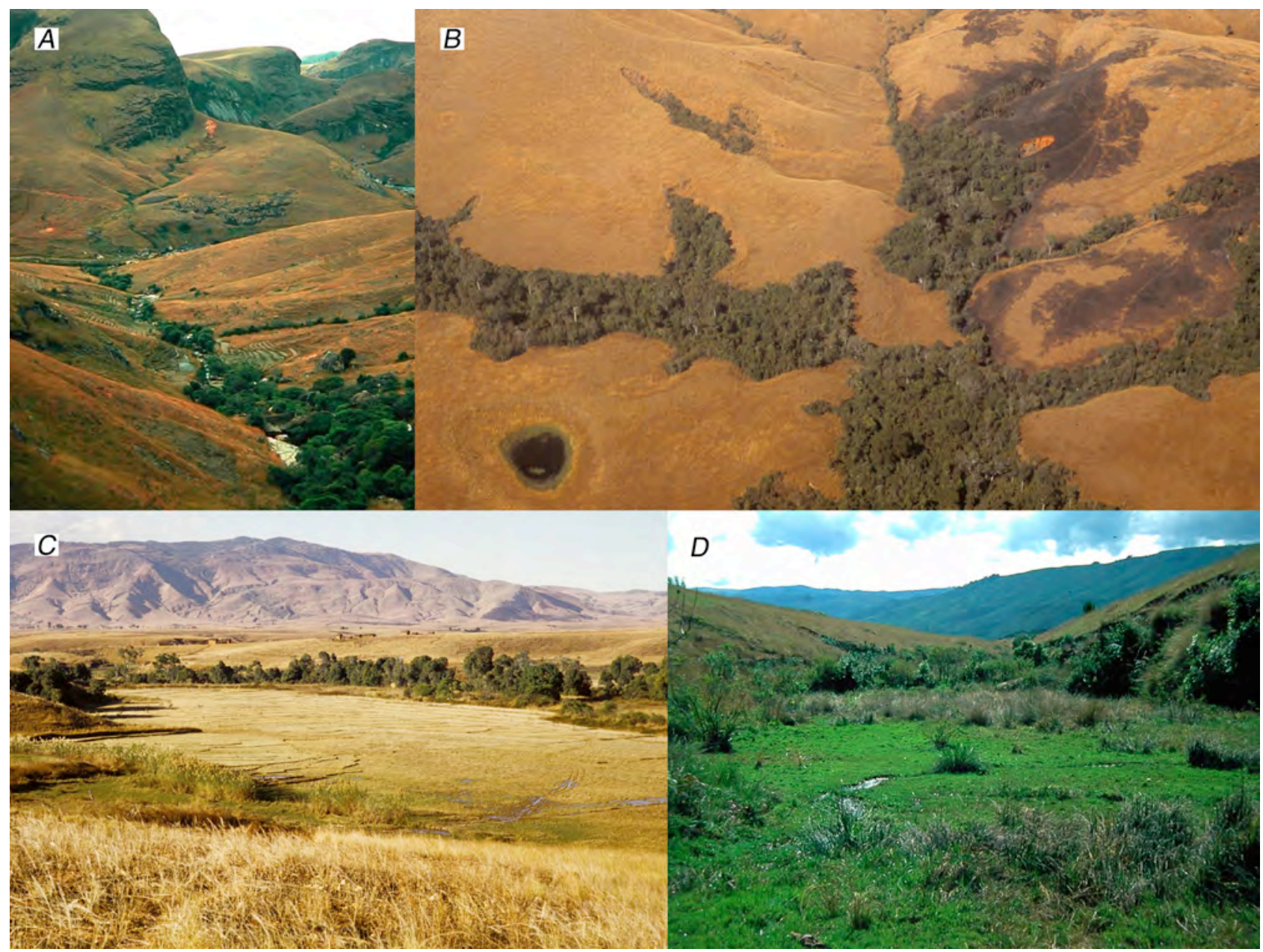

FIGURE 4. Photos of diverse humid soil vegetation formations. (A) Native woody vegetation lining a mountain stream in the southern highlands near Ambalavao. Note also rice terraces along and above stream, and traces of fallow cropfields in grassland. (B) Dense riparian forests in fire refugia stream hollows, as well as a rare pond, in the remote western highlands (towards Bongolava). (C) Gallery forest typical of the middle-west near Tsiroanomandidy. Note floodplain seasonal wetlands developed as irrigated rice fields. (D) Minor moist soil area of poor drainage in small mountain stream hollow in centra highlands (near Antsirabe)

villagers, and on locally negotiated forms of sustainable resource management.

In conclusion, this research demonstrates that studies of environmental change based on aerial photography can offer a level of detail (in scale, and in topography) as well as a depth of history (almost half a century before high resolution satellite images) that provides useful and novel insights. Based on such research tools, the study suggests, in particular, that conservation attention in the highlands should focus more attention on grasslands and remnant small-scale wetlands and gallery forests, rather than just on closed forest patches (which have shrunk, but are better represented to the east) or sclerophyllous woodlands (which appear stable). Grassland and wetland environments are both specialized habitats likely to be valuable to biological diversity as well as crucial building blocks for Malagasy cultural landscapes and food security. In the highlands, agricultural expansion takes place preferentially in these environments. As a result, more research attention should be focused on the biology of these environments (Bond et al. 2008), on their place in rural society (Blanc-Pamard 1986, Rakoto Ramiarantsoa 1996), and on the socio-ecological dynamics of the new landscapes created out of them (Martin et al. 2009, Carrière et al. 2012).

\section{ACKNOWLEDGMENTS}

This research was made possible by funds from the Province of Quebec (FCAR 2002-SC-79002), McGill University, and Monash University. M. Kilinc, J. Kunapo, and K. Jones of Monash's GIS lab skillfully processed, digitized and prepared the data; $B$. Brigham drafted Figures 1 and 3. I gratefully thank particularly B. McConnell and also J. Ramiandrison, H. Razafimampanana, J. Ratsirarson, R. Edmond, S. Chandra, and S. Carrière for diverse inspirations and help, and the two reviewers for their very constructive critiques and suggestions. This research will also appear in different form in a book chapter emphasizing the challenges of integrating political ecological research with land change science. I thank the editors (C. Brannstrom and J. Vadjunec) of that book, titled 'Land Change Science, Political Ecology, and Sustainability' (Earthscan/Routledge, 2013), for their helpful comments and their permission to also publish the project results here.

\section{REFERENCES}

Alvarado, S. T., Buisson, E., Rabarison, H., Rajeriarison, C., Birkinshaw, C. and Lowry II, P. P. 2010. Reintroduction and reinforcement of endangered woody species populations in tapia woodlands, Mount Ibity, Madagascar: protocol and preliminary results. Proceedings of the 7 th European Conference on Ecological Restoration, Avignon, France, pp $1-4$ 
Andreone, F., Carpenter, A. I., Cox, N., du Preez, L., Freeman, K., Furrer, S., Garcia, G., Glaw, F., Glos, J., Knox, D., Köhler, J., Mendelson III, J. R., Mercurio, V., Mittermeier, R. A., Moore, R. D., Rabibisoa, N. H. C., Randriamahazo, H., Randrianasolo, H., Raminosoa, N. R., Ramilijaona, O. R., Raxworthy, C. J., Vallan, D., Vences, M., Vieites, D. R. and Weldon, C. 2008. The challenge of conserving amphibian megadiversity in Madagascar. PLoS Biology 6, 5: e118. (doi:10.1371/journal. pbio.0060118)

Benstead, J. P., de Rham, P. H., Gattolliat, J.-L., Gibon, F.-M., Loiselle, P. V., Sartori, M., Sparks, J. S. and Stiassny, M. L. J. 2003. Conserving Madagascar's freshwater biodiversity. Bioscience 53, 11: 1101-1111. (doi:10.1641/0006-3568(2003)053[1101:CMFB]2.0.CO;2)

Blanc-Pamard, C. 1986. Dialoguer avec le paysage ou comment l'espace écologique est vu et pratiqué par les communautés rurales des hautes terres malgaches. In: Milieux et Paysages: Essai sur Diverses Modalités de Connaissance. Y. Chatelin and G. Riou (eds.), pp 17-36. Masson, Paris.

Blanc-Pamard, C. \& Rakoto Ramiarantsoa, H. 2000. Le Terroir et son Double: Tsarahonenana 1966-1992, Madagascar. IRD Editions, Paris.

Bond, W. J., Silander, J. A., Jr., Ranaivonasy, J. and Ratsirarson, J. 2008. The antiquity of Madagascar's grasslands and the rise of C4 grassy biomes. Journal of Biogeography 35: 1743-1758. (doi:10.1016/j.biocon.2009.12.012)

Bond, W. J. and Parr, C. L. 2010. Beyond the forest edge: Ecology, diversity and conservation of the grassy biomes. Biological Conservation 143, 10: 2395-2404. (doi:10.1016/j.biocon.2009.12.012)

Bosser, J. 1969. Graminées des Pâturages et des Cultures à Madagascar. ORSTOM, Paris.

Burney, D. A., Burney, L. P., Godfrey, L. R., Jungers, W. L., Goodman, S. M., Wright, H. T. and Jull, A. J. T. 2004. A chronology for late prehistoric Madagascar. Journal of Human Evolution 47, 1-2: 25-63. (doi:10.1016/j. jhevol.2004.05.005)

Carrière, S. M. \& Randriambanona, H. 2007. Biodiversité introduite et autochtone: antagonisme ou complémentarité? Le cas de l'eucalyptus à Madagascar. Bois et Forêts des Tropiques 292, 2: 5-21. Available at $<$ http://bft.cirad.fr>

Carrière, S. M., Rodary, E., Méral, P., Serpantié, G., Boisvert, V., Kull, C. A. Lestrelin, G., Lhoutellier, L., Moizo, B., Smektala, G. and Vandevelde, J.-C. 2012. Rio +20 , biodiversity marginalized. Conservation Letters [early view] (doi:10.1111/j.1755-263X.2012.00291.X)

Conservation International, DEF, CNRE \& FTM. 1995. Formations végétales et domaine forestier national de Madagascar (carte 1:1,000,000). CI/DEF/ CNRE/FTM, Antananarivo.

Copsey, J. A., Jones, J. P. G., Herizo, A., Rajaonarison, L. H. and Fa, J. E. 2009. Burning to fish: local explanations for wetland burning in Lac Alaotra, Madagascar. Oryx 43, 3:.403-406. (doi:10.1017/\$0030605309000520)

Coulaud, D. 1973. Les Zafimaniry: un Groupe Ethnique de Madagascar à la Poursuite de la Forêt. Fanontam-Boky Malagasy, Antananarivo.

de Cointet, L. 1897. De Tananarive à Ankavandra. Colonie de Madagascar: Notes, Reconnaissances et Explorations 1, 1: 3-17 and 1, 3: 113-121.

DEF. 1996. Inventaire Ecologique Forestier National. République de Madagascar, Ministère de I'Environnement, Plan d'Actions Environnementales PE1, Direction des Eaux et Forêts, DFS Deutsche Forstservice $\mathrm{GmbH}$, Entreprise d'Etudes de Développement Rural "Mamokatra", Foiben-Taosarintanin'I Madagasikara, Antananarivo.

Delenne, M. 1970. Terroirs en gestation dans le Moyen-Ouest malgache. Études Rurales 37-39: 410-448.

Dolch, R., Fiely, J. L., Ndriamiary, J.-N., Rafalimandimby, J., Randriamampionona, R., Engberg, S. E. and Louis Jr., E. E. 2008. Confirmation of the greater bamboo lemur, Prolemur simus, north of the Torotorofotsy wetlands, eastern Madagascar. Lemur News 13: 14-17.

Durbin, J., Bernard, K. and Fenn, M. 2003. The role of socioeconomic factors in loss of Malagasy biodiversity. In: The Natural History of Madagascar. S. M. Goodman and J. P. Benstead (eds.), pp 142-146. University of Chicago Press, Chicago.

Ellis, E. C. and Ramankutty, N. 2008. Putting people in the map: anthropogenic biomes of the world. Frontiers in Ecology and Environment 6, 8: 439-447. (doi:10.1890/070062)
Elouard, J.-M. \& Gibon, F.-M. 2001. Biodiversité et biotypologie des eaux continentales de Madagascar. Institut de Recherche pour le Développement (IRD) \& Centre National de la Recherche pour I'Environnement (CNRE): 1-447.

Gade, D. W. 1996. Deforestation and its effects in highland Madagascar. Mountain Research and Development 16, 2: 101-116.

Gade, D. W. 2008. Considering Madagascar's deforestation story in paradigmatic and reflexive terms. In: Greening the Great Red Island: Madagascar in Nature and Culture. J. C. Kaufmann (ed.), pp 93-112. Africa Institute of South Africa, Pretoria.

Gasse, F. and Van Campo, E. 1998. A 40,000-yr pollen and diatom record from Lake Tritrivakely, Madagascar, in the southern tropics. Quaternary Research 49, 3: 299-311. (doi:10.1006/qres.1998.1967)

Green, G. M. and Sussman, R. W. 1990. Deforestation history of the eastern rain forests of Madagascar from satellite images. Science 248, 4952: 212-215.

Harper, G. J., Steininger, M. K., Tucker, C. J., Juhn, D. and Hawkins, F. 2007. Fifty years of deforestation and forest fragmentation in Madagascar. Environmental Conservation 34, 4: 325-333. (doi:10.1017/ S0376892907004262)

Humbert, H. and Cours Darne, G. 1965. Carte International du Tapis Végétal et des Conditions écologiques à 1/1.000.000. Notice de la Carte de Madagascar. Travaux de la Section Scientifique et Technique de I'Institut Français de Pondichéry, Hors série 6, Pondichéry.

Jones, J. P. G., Andriahajaina, F. B., Hockley, N. J., Crandall, K. A. and Ravoahangimalala, O. R. 2007. The ecology and conservation status of Madagascar's endemic freshwater crayfish (Parastacidae; Astacoides). Freshwater Biology 52, 9: 1820-1833. (doi:10.1111/j.13652427.2007.01766.x)

Koechlin, J. 1993. Grasslands of Madagascar. In: Ecosystems of the World 8. Natural Grasslands: Eastern Hemisphere and Résumé. R. T. Coupland (ed.), pp 291-301. Elsevier, Amsterdam.

Kremen, C., Cameron, A., Moilanen, A., Phillips, S. J., Thomas, C. D., Beentje, H., Dransfield, J., Fisher, B. L., Glaw, F., Good, T. C., Harper, G. J., Hijmans, R. J., Lees, D. C., Louis Jr., E., , Nussbaum, R. A., Raxworthy, C. J., Razafimpahanana, A., Schatz, G. E., Vences, M., Vieites, D. R., Wright, P. C. and Zjhra, M. L. 2008. Aligning conservation priorities across taxa in Madagascar with high-resolution planning tools. Science 320, 5873: 222-226. (doi:10.1126/science.1155193)

Kull, C. A. 1998. Leimavo revisited: Agrarian land-use change in the highlands of Madagascar. Professional Geographer 50, 2: 163-176. (doi:10.1111/0033-0124.00112)

Kull, C. A. 2003. Uapaca woodlands. In: The Natural History of Madagascar. S. M. Goodman and J. P. Benstead (eds.), pp 393-398. University of Chicago Press, Chicago.

Kull, C. A. 2004. Isle of Fire: The Political Ecology of Landscape Burning in Madagascar. University of Chicago Press, Chicago.

Kull, C. A. 2008. Saving land with a spade: Human landscape transformations in the Madagascar highlands. In: Greening the Great Red Island Madagascar in Nature and Culture. J. C. Kaufmann (ed.), pp 113-135. Africa Institute of South Africa, Pretoria.

Kull, C. A., Tassin, J. and Rangan, H. 2007. Multifunctional, scrubby, and invasive forests? Wattles in the highlands of Madagascar. Mountain Research and Development 27, 3: 224-231. (doi:10.1659/mrd.0864)

Kull, C. A., Tassin, J., Moreau, S., Rakoto Ramiarantsoa, H., Blanc-Pamard, C. and Carrière, S. M. 2012. The introduced flora of Madagascar. Biological Invasions 14, 4: 875-888. (doi:10.1007/s10530-011-0124-6)

Langrand, O. \& Wilmé, L. 1993. Protection des zones humides et conservation des espèces d'oiseaux endémiques de Madagascar. In R.T. Wilson (Ed.). Proceedings of the 8th Pan-African Ornithological Congress:Birds and the African Environment. Musée Royal de I'Afrique Centrale, Tervuren Annalen 268: 201-208.

Lillesand, T. M. and Kiefer, R. W. 1994. Remote sensing and image interpretation. Wiley and Sons, New York.

Lowry II, P. P., Schatz, G. E. and Phillipson, P. B. 1997. The classification of natural and anthropogenic vegetation in Madagascar. In: Natural Change and Human Impact in Madagascar. S. M. Goodman and B. D. Patterson (eds.), pp 93-123. Smithsonian Institution Press, Washington. 
Martin, E. A., Ratsimisetra, L., Laloë, F. and Carrière, S. M. 2009. Conservation value for birds of traditionally managed isolated trees in an agricultural landscape of Madagascar. Biodiversity and Conservation 18, 10 : 2719-2742. (doi:10.1007/s10531-009-9671-X)

McConnell, W. J. 2002. Madagascar: Emerald isle or paradise lost? Environment 40: 10-22.

McConnell, W. J. and Sweeney, S. P. 2005. Challenges of forest governance in Madagascar. The Geographical Journal 171, 3: 223-238. (doi:10.1111/ j.1475-4959.2005.00162.x)

McCusker, B. and Weiner, D. 2003. GIS representations of nature, political ecology, and the study of land use and land cover change in South Africa. In: Political Ecology: An Integrative Approach to Geography and Environment-Development Studies. K. S. Zimmerer and T. J. Bassett (eds.), pp 201-218. Guilford Press, London.

Moat, J. and Smith, P. (eds). 2007. Atlas of the Vegetation of Madagascar / Atlas de la Végétation de Madagascar. Royal Botanic Gardens, Kew, Richmond, Surrey, UK.

Pareliussen, I., Olsson, E. G. A. and Armbruster, W. S. 2006. Factors limiting the survival of native tree seedlings used in conservation efforts at the edges of forest fragments in upland Madagascar. Restoration Ecology 14, 2: 196-203. (doi:10.1111/j.1526-100X.2006.00121.x)

Pollini, J. 2010. Environmental degradation narratives in Madagascar: From colonial hegemonies to humanist revisionism. Geoforum 41, 5: 711-722. (doi:10.1016/j.geoforum.2010.04.001)

Raison, J.-P. 1984. Les Hautes Terres de Madagascar et leurs Confins Occidentaux: Enracinement et Mobilité des Sociétés Rurales. Editions Karthala, Paris.

Rakoto Ramiarantsoa, H. 1995. Chair de la Terre, il de l'Eau... Paysanneries et recompositions de campagnes en Imerina (Madagascar). Éditions de I'Orstom, Paris.

Ralainasolo, F. B., Waeber, P. O., Ratsimbazafy, J., Durbin, J. and Lewis, R. 2006. The Alaotra gentle lemur: Population estimation and subsequent implications. Madagascar Conservation \& Development 1, 1: 9-10.

Rasoavarimanana, M.-A. 1997. Le marais d'altitude de Torotorofotsy et son environnement socio-économique. Agriculture et Développement 14: 3-10.
Ratsirarson, J. \& Goodman, S. M. (eds). 2000. Monographie de la Forêt d'Ambohitantely. Recherches pour le Développement, Série Sciences Biologiques. Centre d'Information et de Documentation Scientifique et Technique, Antananarivo 16.

Razafindramanga Minoniaina, L. 1994. Zonage de I'occupation des sols en Imerina à partir de la télédetection. Akon'ny Ala 14: 19-31.

Repoblikan'i Madagasikara. 1993. Recensement Général de la Population et de I'Habitat: Résultats Préliminaires. B.D.E., Antananarivo.

Robbins, P. 2001. Fixed categories in a portable landscape: The causes and consequences of land cover categorization. Environment and Planning A 33: 161-179. (doi:10.1068/a3379)

SSG (Service de Statistique Générale). 1953. Annuaire Statistique de Madagascar, Vol. 1 1938-1951. Imprimerie Officielle, Tananarive.

Tassin, J., Bellefontaine, R., Roger, E. \& Kull, C. A. 2009a. Evaluation préliminaire des risques d'invasion par les essences forestières à Madagascar. Bois et Forêts des Tropiques 299, 1: 27-36.

Tassin, J., Rakotomanana, R. \& Kull, C. A. 2009b. Proposition d'un cadre de représentation des bioinvasions en milieu rural: cas de Acacia dealbata à Madagascar. Bois et Forêts des Tropiques 300, 2: 3-14.

Vågen, T.-G. 2006. Remote sensing of complex land use change trajectories - a case study from the highlands of Madagascar. Agriculture, Ecosystems \& Environment 115, 1-4: 219-228. (doi:10.1016/j. agee.2006.01.007)

Vanacker, V., Govers, G., Tacuri, E., Poesen, J., Dercon, G. and Cisneros, F. 2000. Using sequential aerial photographs to detect land-use changes in the Austro Ecuatoriano. Revue de Géographie Alpine 88, 3: 65-75.

Vences, M., Wollenberg, K. C., Vieites, D.R., and Lees, D. C. 2009. Madagascar as a model region of species diversification. Trends in Ecology \& Evolution 24, 8: 456-465. (doi:10.1016/j.tree.2009.03.011)

Warner, W. S., Graham, R. W. and Read, R. E. 1996. Small Format Aerial Photography. Whittles Publishing, Caithness, Scotland.

Willis, K. J., Gillson, L. and Virah-Sawmy, M. 2008. Nature or nurture: The ambiguity of C4 grasslands in Madagascar. Journal of Biogeography 35, 10: 1741-1742. (doi:10.1111/j.1365-2699.2008.01985.x) 